\title{
6. GEOCHEMISTRY OF ZERO-AGE N-MORB FROM HOLE 648B, ODP LEGS 106-109, M.A.R., $22^{\circ} \mathrm{N}^{1}$
}

\author{
G. Di Donato, ${ }^{2}$ J. L. Joron,${ }^{3}$ M. Treuil,${ }^{3}$ and M. Loubet ${ }^{2}$
}

\begin{abstract}
Legs 106-109 achieved the first basaltic bare-rock drill hole, on a small volcano (Serocki volcano) located on the flanks of the rift valley in the MAR about $70 \mathrm{~km}$ south of the Kane fracture zone. Because of severe technical difficulties only $50.5 \mathrm{~m}$ of basalt below seafloor was recovered.

Geochemical analysis shows that the recovered basalts display typical N-MORB characteristics as expected in this segment of the Mid-Atlantic ridge. The lava flows display rather equivalent geochemical characteristics all over the drilled section and show the imprint of a previous magmatic differentiation suffered by the magmas before their emission, indicative of a fractional crystallization of plagioclase-bearing cumulates. The incompatible and alkali element content of these 648B magmas is very low, a feature which resembles those of other N-MORB.

The geochemical characteristics of these basalts look closely similar to those of basalts from the same flow line emitted respectively $10 \mathrm{~m} . \mathrm{y}$. (Hole 395, Legs 45-46), and $110 \mathrm{~m} . \mathrm{y}$. (Hole 417A, Legs 51-53) ago, supporting the persistence in this ridge segment of a mantle source with depleted characteristics over the last 110 m.y., but with some variations in the degree of depletion of the source along this period.

Although these rocks appear fresh, the imprint of an incipient low temperature alteration can be noticed in a few samples, as evidenced by slight increases of alkali, $\mathrm{U}$ elements, and ${ }^{87} \mathrm{Sr} /{ }^{86} \mathrm{Sr}$ isotopic compositions.
\end{abstract}

\section{INTRODUCTION}

Hole 648B was drilled during the ODP Legs 106 and 109, in a first attempt to drill directly basaltic bare rocks on a ridge system (Shipboard Scientific Party, 1988).

The site chosen for this first bare-rock drill hole was the rift valley of the Mid-Atlantic Ridge (MAR), about $70 \mathrm{~km}$ south of the Kane fracture zone, in an area which was one of the first surveyed on the MAR (Melson et al., 1968; Frey et al., 1974; Bryan et al., 1976). A diversity of petrological and geochemical studies performed in this area showed it was composed mainly of typical normal tholeiitic basalts (N-MORB) (Bryan et al., 1976, 1981; Bougault, 1980; Bougault et al. 1978, 1979). The site was a small volcano (Serocki volcano) situated in the median valley of the ridge.

Due to the extremely difficult drilling conditions, Hole $648 \mathrm{~B}$ was cored only to a total depth of $50.5 \mathrm{mbsf}$, so that the main objectives of the program (better understanding of the complex and interrelated volcanic, tectonic, and hydrothermal process occurring at spreading centers) became unrealizable.

Nevertheless, the material collected is interesting, as it is representative of rather fresh zero-age rocks from this zone (some slight sediment cover, some palagonitization, and alteration suggest, however, an age slightly older than zero). Most often, if not always, oceanic rocks are subject to alteration processes which modify their composition, sometimes significantly. The modifications of the composition depend on the type of the alteration process (low $\mathrm{T}$ alteration, high $\mathrm{T}$ hydrothermal). Although these have now been more and more thoroughly analyzed (Humphris and Thompson, 1978; Hon-

\footnotetext{
${ }^{1}$ Detrick. R., Honnorez, J., Bryan, W. B., Juteau, T., et al., 1990. Proc. ODP, Sci. Results, 106/109: College Station, TX (Ocean Drilling Program).

${ }^{2}$ Université Paul Sabatier. Laboratoire de Mineralogie, 38 rue des 36 Ponts, 31400 Toulouse, France.

${ }^{3}$ Laboratoire Pierre Sue, Saclay, France, and Laboratoire de Geochimie systematique et comparee, Université Paris 6, 2 place Jussieu, 75230 Paris Cedex 05, France.
}

norez, 1981; Staudigel and Hart, 1983; Alt et al., 1986, as examples), the exact composition of the original rocks remains obscure. These fresh $648 \mathrm{~B}$ basalts could provide information on the uncontaminated composition of this rock type in this ridge segment.

This paper deals with the geochemical characteristics of these Hole $648 \mathrm{~B}$ basalts. After recalling some main features of MORB and more precisely the MAR basalts known to date, we will (1) present the data (major elements, X-Ray fluorescence and isotope dilution trace element data, ${ }^{87} \mathrm{Sr} /{ }^{86} \mathrm{Sr}$ isotope composition), (2) underline the main geochemical characteristics of these basalts, and (3) show the effects of low temperature alteration on these rocks and on equivalent rock types erupted on the same ridge flow-line at an earlier date. Alkali element distributions which are very sensitive to this process, will be used for this analysis.

\section{MORB AND MAR BASALTS}

Since some previous studies on oceanic basalts performed in the Atlantic Ocean not far from the area where Legs 106-109 were carried out (Bryan et al., 1976; Bryan and Sargent, 1978; Bougault et al., 1978), knowledge of ridge basalts has considerably increased. From the first hypothesis of uniformly depleted basalts from one ridge end to the other (reflected in the term MORB), clearly distinguishing them from the enriched oceanic island basalts, a different picture has now been arrived at with basalts from mid-ocean spreading ridges displaying a relatively wide range of compositions and even covering the oceanic island basalt domain.

On the basis of many data, the oceanic basalt composition domain is widely acknowledged (see Zindler and Hart, 1984; Loubet et al., 1988, for a review of the isotopic and trace element compositions). This wide range of compositions is attributed to mantle heterogeneity, the extent and nature of which is the subject of wide debate at the present time (Allegre, 1982; Hofmann and White, 1982; Ringwood, 1982; Allegre and Turcotte, 1986; Zindler and Hart, 1986). The existence of different compositional domains in the oceans on a large scale is another important question of the last few 
years (Dupre and Allegre, 1983; Hart, 1984). However the significance of such compositional domains in the mantle structure is still the subject of speculation (Schilling, 1973; Hart, 1984, Allegre and Turcotte, 1986).

In the Atlantic Ocean, ridge basalt compositional variations from north to south have been evidenced by extensive dredging along the axis (Schilling, 1973; White and Schilling, 1978; Bougault and Treuil, 1980) and drilling accomplished during numerous DSDP legs. This detailed analysis has established clear relationships between MAR lava geochemical characters, and other geophysical (heat flow) and geomorphological (ridge depth) features (Schilling, 1973; Le Douaran and Francheteau, 1981; Schilling et al., 1983).

1. Enriched basalts characterized by more radiogenic $\mathrm{Sr}$, $\mathrm{Pb}$, and less radiogenic $\mathrm{Nd}$ isotopic compositions, light $\mathrm{REE}$ enriched patterns, are found in anomalous ridge segments, with very high heat flow and elevated topography. They occur from $34^{\circ} \mathrm{N}$ to $49^{\circ} \mathrm{N}$ being centered on the Azores platform and Famous zone (White and Schilling, 1978; Langmuir et al., 1977; Weaver et al., 1987; Hertogen et al., 1985; Drake et al., 1985; Bougault et al., 1985) and north of $49^{\circ} \mathrm{N}$ being centered on Iceland (from $49^{\circ}$ to $63^{\circ} \mathrm{N}$ ) (Schilling, 1973, 1975; Schilling et al., 1983; Wood et al., 1979).

2. Transitional basalts found between $39^{\circ}$ and $25^{\circ} \mathrm{N}$, emerge away from the topographic heights of Iceland and the Azores platform and toward the normal ridge segments located in the south. The existence of geochemical gradients from the enriched alkali type basalts to the normal type basalts, has been clearly shown (Bougault et al.,1978; Bougault and Treuil, 1980).

3. Normal type basalts characterized by LREE depleted patterns, less radiogenic $\mathrm{Sr}, \mathrm{Pb}$, and more radiogenic $\mathrm{Nd}$ isotopic compositions emerge typically in a large area located south of the Kane fracture zone $\left(25^{\circ} \mathrm{N}\right)$, where the ridge is much deeper and characterized by low heat flow (Brayn et al., 1976; Bougault, 1980; Bougault et al., 1978, 1979).

Results of drilling on a flow line south of the Kane fracture zone show that this type of basalt was produced with rather uniform composition over a long period of time: Holes 395 and $396\left(22^{\circ} \mathrm{N}\right)$ realized during the DSDP Legs 45 and 46 in a 10 -m.y.-old oceanic crust; Holes 417 and $418\left(25^{\circ} \mathrm{N}\right)$ drilled during the DSDP Legs 51, 52, and 53 in a 110 -m.y.-old oceanic crust (Donnelly et al., 1980; Bougault et al., 1979; Joron et al., 1979).

\section{ANALYTICAL TECHNIQUES}

The major elements except $\mathrm{Na}$ and $\mathrm{K}$ were measured by X-Ray Fluorescence (XRF) on the Siemens X-Ray Spectrometer of the Toulouse University Petrological laboratory using fused pellets with the classical heavy absorber method. $\mathrm{Na}$ and $\mathrm{K}$ were analyzed by flame spectrometry at the Mineralogical Laboratory of Toulouse University (MLTU). Volatile elements were determined by loss ignition at $1000^{\circ} \mathrm{C}$. Analytical precision is better than $2 \%$.

XRF spectrometry using the pressed powder pellets (with a $10 \%$ weight binder) method was used to analyze a set of trace elements (Ti, $\mathrm{V}, \mathrm{Cr}, \mathrm{Co}, \mathrm{Ni}, \mathrm{Zr}$ ). Matrix, instrument as well as interference, and enhancement effects were corrected by computation as per Bougault et al. (1977). Selected international rock standards (Nancy CRPG standards) were used for calibration. Analytical precision for trace elements is within $5 \%-10 \%$ for concentrations higher than $20 \mathrm{ppm}$, and $2 \mathrm{ppm}$ at concentrations lower than $20 \mathrm{ppm}$.

$\mathrm{REE}, \mathrm{Rb}, \mathrm{Sr}$, and $\mathrm{Ba}$ analysis were measured using isotope dilution at the MLTU on a modified CAMECA 206 THN mass spectrometer. Precision is estimated at around $2 \%$. Chemical separation of the elements was carried out on a AG $50 \mathrm{~W}$ (200-400 mesh) cationic ion exchange column. Sr was separated from the $\mathrm{Ca}$ using ammonium citrate as a complexing agent. REE were separated for mass spectrometry analysis in three fractions on a HDEHP (Di(2ethylhrxyl) orthophosphoric acid) column (Richard et al., 1976).
The neutron activation method used in Saclay to measure a set of trace elements was pure instrumental activation analysis (without chemical separation), using epithermal neutron irradiation (OSIRIS Reactor in Sarclay-CEA-Groupe Pierre Sue). This method is described in Jaffrezic et al. (1977) and Bougault et al. (1978). Irradiation was performed under Cd vials. Several measurements were made with a $\mathrm{Ge}-\mathrm{Li}$ detector (resolution $2 \mathrm{keV}$ at $1.33 \mathrm{MeV}$ ) at different times from 4 days to 1 month after irradiation. The reference international standards were GSN and BCR 1.

$\mathrm{Sr}$ isotopic composition measurements were performed on a FINNIGAN 261 automatic multicollector mass spectrometer at the MLTU. NBS 987 Standard was measured with a ${ }^{87} \mathrm{Sr} /{ }^{86} \mathrm{Sr}$ ratio of $0.71020 \pm 0.00002(2 \sigma \sqrt{N})$. Correction of the mass discrimination effect is performed by normalizing the ${ }^{87} \mathrm{Sr} /{ }^{86} \mathrm{Sr}$ ratio to a value of 8.375209.

\section{HOLE 648B BASALTS}

\section{Data}

The lithostratigraphic sequence established in this hole is shown in the Figure 1. Three lithological types are identified in the rocks recovered: (1) aphyric to sparsely plagioclase phyric basalts; (2) vesicular to sparsely plagioclase phyric basalts; and (3) massive holocrystalline, sparsely olivine plagioclase phyric basalts, in that order; however, due to rubble falling into the hole, pieces from types 1 and 2 were frequently found in the deeper cores.

The rocks analyzed cover these three lithological types. The major element, minor element, and ${ }^{87} \mathrm{Sr} /{ }^{86} \mathrm{Sr}$ compositions of the Hole 648B basaltic samples studied are listed in Tables 1 and 2. A petrographical description of these basalts can be found in companion studies in this volume. In our analysis of the data we will underline some of the main geochemical characters of these rocks.

\section{Hole 648B main geochemical features}

\section{N-type MORB}

As expected, basalts from Hole 648B display typical $\mathrm{N}$ MORB characteristics:

1. ${ }^{87} \mathrm{Sr} /{ }^{86} \mathrm{Sr}$ compositions. They fall in the lower limit of the MORB composition field as N-MORB usually do.

2. Depleted chondrite normalized patterns. In Figure 2, the incompatible elements have been plotted in the classical Coryell-Masuda extended representation, in which the content of normalized to chondritic elements are plotted in function of their estimated degree of incompatibility in basaltic magmas (Wood et al., 1979; Bougault, 1980). Hole 648B basalts display a typically depleted pattern, with the depletion increasing progressively from the lesser to the more incompatible elements.

3. Low values of $\mathrm{H}+/ \mathrm{H}$ - ratios. The ratio of content of a more hygromagmatophile $(\mathrm{H}+)$ over a less hygromagmatophile $(\mathrm{H}-)$ element, displays low values $(\mathrm{H}=$ hygromagmatophile type element, i.e., elements which highly prefer the melt during solid-melt fractionation, see definition in Treuil and Joron (1975)). The value of such ratios in these $22^{\circ} \mathrm{N}$ MAR basalts are among the lowest found in oceanic basalts. This concerns ratios such as $\mathrm{Th} / \mathrm{U}$ (1.6 to 2.5$), \mathrm{Th} / \mathrm{La}(0.033$ to $0.045), \mathrm{Th} / \mathrm{Ta}$ (0.64 to 0.81 ) (Fig. 3). Values of these ratios are clearly lower than the classically assumed range of primitive values of these ratios, respectively 3.8 to $4.3(\mathrm{Th} / \mathrm{U}), 0.093$ to $0.14(\mathrm{Th} / \mathrm{La})$, and 1.3 to $2.05(\mathrm{Th} / \mathrm{Ta})$.

\section{Magmas previously differentiated by fractional crystallization}

A rather good constancy in the major and minor element compositions of these basalts is noticed throughout the drilled 


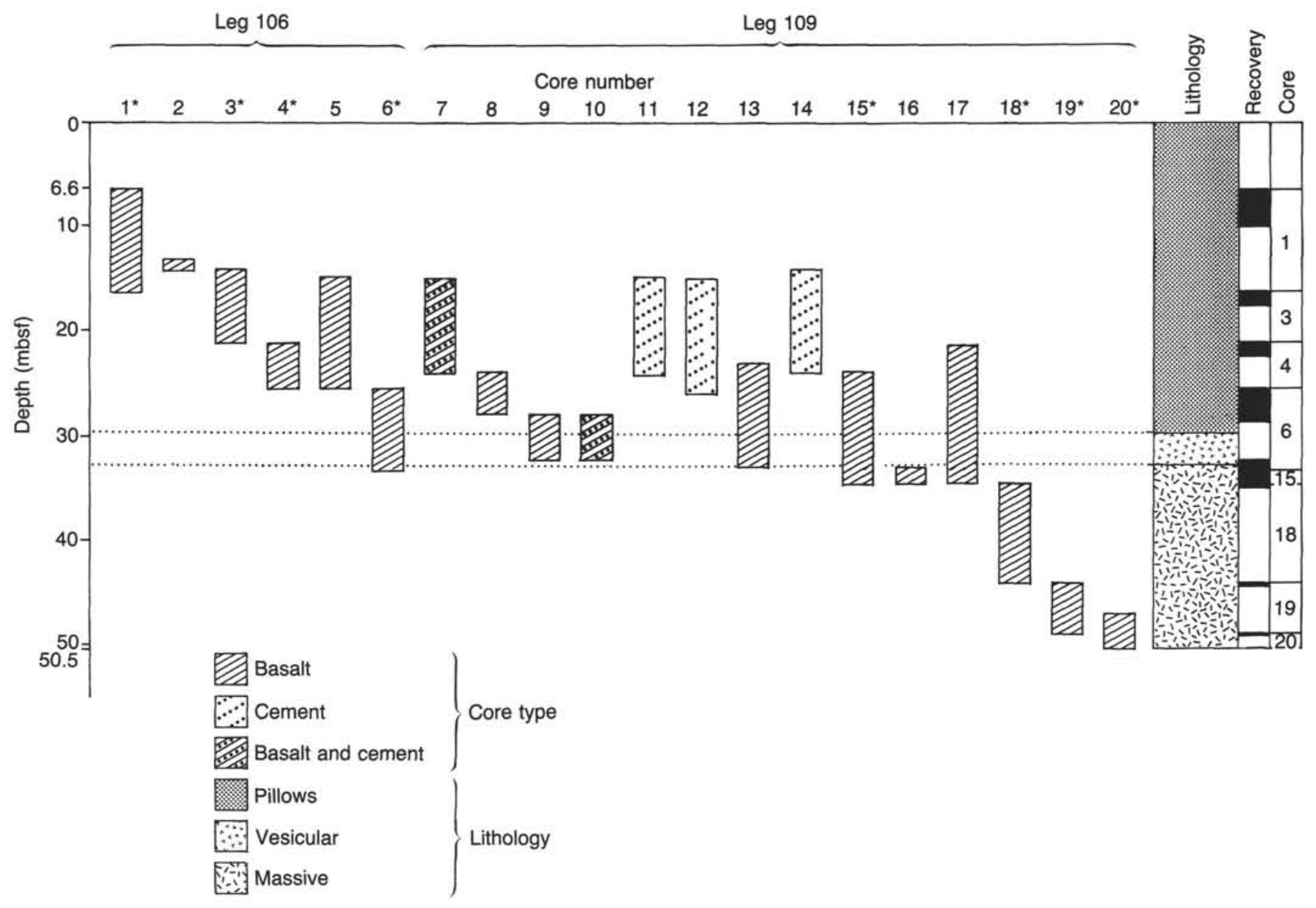

Figure 1. Proposed lithostratigraphy of Hole 648B (from Shipboard Scientific Party, 1988); stratigraphic position of each core is shown. Cores marked by an asterisk denote recovery from in situ basement. Shaded intervals in the Recovery column show total recovery from corresponding section of hole. Cores that advanced the hole are numbered in the Core column.

Table 1. Major element and ${ }^{87} \mathrm{Sr}{ }^{86} \mathrm{Sr}$ compositions of Hole $648 \mathrm{~B}$ and AII interlaboratory standard basalts whole rocks. XRF and flame photometry $(\mathrm{K})$ analyses performed in Toulouse University Mineralogical laboratory. AII 92-29-1 from Hole 417A (Staudigel, 1979).

\begin{tabular}{|c|c|c|c|c|c|c|c|c|c|c|}
\hline & $\begin{array}{c}\mathrm{P} \\
1 \mathrm{R} 1 \\
12-14\end{array}$ & $\begin{array}{c}P \\
1 \mathrm{R} 1 \\
14-18\end{array}$ & $\begin{array}{c}\mathrm{P} \\
1 \mathrm{R} 2 \\
101-103\end{array}$ & $\begin{array}{c}\mathrm{V} \\
6 \mathrm{R} 1 \\
113-115\end{array}$ & $\begin{array}{c}\mathrm{P} \\
7 \mathrm{R} 2 \\
30-33\end{array}$ & $\begin{array}{c}\mathrm{V} \\
9 \mathrm{R} 1 \\
16-21\end{array}$ & $\begin{array}{c}P \\
13 R 1 \\
22-25\end{array}$ & $\begin{array}{c}\mathrm{M} \\
16 \mathrm{R} 1 \\
73-75\end{array}$ & $\begin{array}{c}\mathrm{M} \\
18 \mathrm{R} 1 \\
42-46\end{array}$ & $\begin{array}{c}\text { STAND } \\
\text { RII }\end{array}$ \\
\hline $\mathrm{SiO}_{2}$ & 49.59 & 49.75 & 49.27 & - & 49.50 & 50.11 & 50.20 & 49.27 & 47.66 & 48.90 \\
\hline $\mathrm{TiO}_{2}$ & 1.71 & 1.94 & 1.71 & - & 1.66 & 1.68 & 1.69 & 1.63 & 1.65 & 1.76 \\
\hline $\mathrm{Al}_{2} \mathrm{O}_{3}$ & 15.44 & 14.39 & 15.26 & - & 15.68 & 15.42 & 15.57 & 15.47 & 14.83 & 15.10 \\
\hline $\mathrm{Fe}_{2} \mathrm{O}_{3}$ & 11.21 & 12.36 & 11.12 & - & 10.99 & 11.27 & 11.13 & 10.86 & 11.07 & 11.28 \\
\hline $\mathrm{MnO}^{\circ}$ & 0.19 & 0.20 & 0.18 & - & 0.18 & 0.19 & 0.19 & 0.18 & 0.18 & 0.17 \\
\hline $\mathrm{MgO}$ & 7.94 & 7.58 & 7.89 & - & 8.19 & 8.29 & 7.65 & 8.06 & 7.98 & 7.78 \\
\hline $\mathrm{P}_{2} \mathrm{O}_{5}$ & 0.18 & 0.24 & 0.19 & - & 0.20 & 0.18 & 0.20 & 0.17 & 0.18 & 0.18 \\
\hline $\mathrm{CaO}$ & 11.26 & 10.82 & 11.29 & - & 11.39 & 11.15 & 11.37 & 11.42 & 11.29 & 11.18 \\
\hline $\mathrm{K}_{2} \mathrm{O}$ & 0.19 & 0.26 & 0.17 & - & 0.22 & 0.22 & 0.19 & 0.09 & 0.21 & 0.15 \\
\hline $\mathrm{Na}_{2} \mathrm{O}$ & 3.20 & 3.00 & 3.10 & - & 2.95 & 2.85 & 3.11 & 3.00 & 3.07 & 3.10 \\
\hline $\mathrm{H}_{2} \mathrm{O}$ & - & 0.18 & - & - & - & - & - & 0.04 & - & 0.95 \\
\hline Total & 100.91 & 100.72 & 100.18 & - & 100.96 & 101.36 & 101.30 & 100.19 & 96.12 & 100.50 \\
\hline${ }^{87} \mathrm{Sr} /{ }^{86} \mathrm{Sr}$ & & & & 0.702506 & 0.702352 & & & 0.702439 & 0.702388 & \\
\hline 2 sigma & & & & 0.000020 & 0.000018 & & & 0.000020 & 0.000020 & \\
\hline
\end{tabular}

$\mathrm{P}=$ pillow unit, $\mathrm{V}=$ vesicular unit, $\mathrm{M}=$ massive Unit (see Fig. 1). 
Table 2. Trace element content of Hole 648B and AII interlaboratory standard basalts whole rocks. AII 92-29-1 from Hole 417A (Staudigel, 1979). XRF and isotope dilution analyses performed in Toulouse University Mineralogical laboratory. Neutron activation analysis performed in Pierre Sue Laboratory, CEA Saclay.

\begin{tabular}{|c|c|c|c|c|c|c|c|c|c|c|c|c|c|c|c|c|c|c|}
\hline & $\begin{array}{c}\mathrm{Ti} \\
\mathrm{XRF}\end{array}$ & $\begin{array}{c}\text { V } \\
\text { XRF }\end{array}$ & $\begin{array}{c}\mathrm{Cr} \\
\mathrm{XRF}\end{array}$ & $\begin{array}{c}\mathrm{Cr} \\
\mathrm{NAA}\end{array}$ & $\begin{array}{c}\text { Co } \\
\text { XRF }\end{array}$ & $\begin{array}{c}\text { Co } \\
\text { NAA }\end{array}$ & $\begin{array}{c}\mathrm{Ni} \\
\mathrm{XRF}\end{array}$ & $\begin{array}{c}\mathrm{Ni} \\
\mathrm{NAA}\end{array}$ & $\begin{array}{c}\mathrm{Sc} \\
\mathrm{NAA}\end{array}$ & $\underset{\mathrm{XRF}}{\mathrm{Zn}}$ & $\underset{\mathrm{XRF}}{\mathrm{Zr}}$ & $\begin{array}{c}\mathrm{Zr} \\
\mathrm{NAA}\end{array}$ & $\underset{\mathrm{XRF}}{\mathrm{Y}}$ & $\begin{array}{l}\mathrm{Rb} \\
\mathrm{ID}\end{array}$ & $\begin{array}{c}\mathrm{Rb} \\
\mathrm{NAA}\end{array}$ & $\begin{array}{l}\mathrm{Sr} \\
\mathrm{ID}\end{array}$ & $\underset{\text { XRF }}{\mathrm{Sr}}$ & $\begin{array}{l}\mathrm{Ba} \\
\mathrm{ID}\end{array}$ \\
\hline $\begin{array}{l}\text { IR2 } \\
12-14\end{array}$ & 10260 & 317 & 261 & 241 & 39 & 40.9 & 101 & 110 & 36.4 & 79 & 113 & 137 & 41 & - & - & - & 144 & - \\
\hline $\begin{array}{l}1 R 1 \\
14-18\end{array}$ & 11640 & 362 & 219 & 193 & 38 & 42.6 & 94 & 100 & 40.6 & 95 & 127 & 146 & 53 & - & 1.7 & - & 140 & - \\
\hline $\begin{array}{l}\text { 1R2 } \\
101-103\end{array}$ & 10260 & 310 & 251 & 233 & 33 & 41.0 & 102 & 110 & 36.2 & 81 & 106 & 126 & 45 & 1.44 & - & - & 141 & - \\
\hline $\begin{array}{l}\text { 6R1 } \\
113-115\end{array}$ & - & - & - & - & - & - & - & - & - & - & - & - & - & 3.52 & - & 146 & - & 7.87 \\
\hline $\begin{array}{l}7 R 2 \\
30-33\end{array}$ & 9960 & 300 & 251 & 232 & 33 & 42.2 & 100 & 106 & 35.3 & 77 & 103 & 107 & 43 & 3.84 & - & 145 & - & - \\
\hline $\begin{array}{l}9 \mathrm{R} 1 \\
16-21\end{array}$ & 10080 & 316 & 274 & 237 & 39 & 40.1 & 101 & 106 & 35.2 & 79 & 108 & 117 & 46 & - & 1.2 & - & 146 & - \\
\hline $\begin{array}{l}13 R 1 \\
22-25\end{array}$ & 10140 & 321 & 260 & 243 & 37 & 39.8 & 102 & 105 & 35.3 & 80 & 108 & 133 & 44 & - & 1.3 & - & 148 & - \\
\hline $\begin{array}{l}16 \mathrm{R} 1 \\
73-75\end{array}$ & 9780 & 330 & 255 & 240 & 36 & 40.9 & 109 & 111 & 35.3 & 78 & 103 & 113 & 45 & 2.68 & - & 142 & - & - \\
\hline $\begin{array}{l}18 \mathrm{R} 1 \\
42-46\end{array}$ & 9900 & 279 & 254 & 246 & 35 & 41.0 & 90 & 106 & 36.5 & 77 & 110 & 122 & 43 & 2.11 & - & 149 & - & - \\
\hline $\begin{array}{l}\text { STAND } \\
\text { RII }\end{array}$ & 10560 & 343 & 271 & - & 59 & - & 101 & - & - & 81 & 113 & - & 47 & - & - & 134 & - & - \\
\hline
\end{tabular}

section with the exception of the alkali and earth alkaline elements $(\mathrm{K}, \mathrm{Rb}, \mathrm{Ba})$ which are at a very low level in these rocks and which are known to be particularly sensitive to alteration processes (discussed below).

Of particular significance in these rocks is the constancy of the ratio of some hygromagmatophile elements such as Th and Ta. This is indicative of an origin of the magmas from a uniform source. In detail, however, some slight but significant variations of compositions are noticed: (1) in the absolute REE contents (3.75 to $4.88 \mathrm{ppm}$ ); (2) in the contents of elements such as $\mathrm{Ni}$ and $\mathrm{Cr}$, the $\mathrm{Cr}$ content appearing roughly correlated with $\mathrm{Mg}$; and (3) in the ratio of some incompatible to less-incompatible elements such as $\mathrm{Th} / \mathrm{La}(0.03$ to 0.045$)$ and $\mathrm{Sm} / \mathrm{Yb}(0.85$ to 1.04$)$. Variation type (3) supports the existence in the drilled section of different batches of magma rather than a unique flow. Variation types (1) and (2) tend to indicate some differentiation of the magmas either before or after the emission and/or support also the multibatch process. Some differences in the $\mathrm{Sr}$ isotopic compositions are noticed among the samples analyzed which look greater than the analytical uncertainties. Such variations might be indicative of this multiflow process. However, these variations might result as well from alteration effects influencing these basalts after their formation, as discussed below.

The Ni content of these basalts $(120 \mathrm{ppm})$ appears too low for primary magmas derived directly from the partial melting of a mantle peridotite. Classical estimations of $\mathrm{Ni}$ content for such mantle-derived primary magmas range from 250 to 350 ppm (Allegre and Minster, 1978; Tual et al., 1985, for example). This indicates that the $648 \mathrm{~B}$ lavas are representative of magmas previously differentiated in a magma chamber through fractional crystallization. Another sign of such a previous differentiation process can be found in the $\mathrm{Eu}$ and $\mathrm{Sr}$ negative anomalies noticed in the REE extended chondrite normalized patterns of these basalts (Fig. 2). Such Eu and $\mathrm{Sr}$ anomalies are indicative of a previous fractional crystallization of plagioclase-bearing cumulates from the primitive magmas. A detailed analysis of phenocryst plagioclases from these basalts presented in a companion paper (Eissen and Humler, this volume) evidences a chemical zoning in these phases. This chemical zoning is a clear indication of a previous differentiation history of these magmas in the magma chamber, which corroborates the geochemical features.

Persistency of a source with depleted characteristics over the last 110 m.y. in this ridge segment (with some variations in the degree of depletion of the source).

Tholeiitic basalts erupted in an oceanic ridge environment are usually thought to have been formed through a rather large degree of partial melting $(15 \%-20 \%)$. It can then easily be shown that in such conditions the ratios of highly incompatible type elements in the magmas should be somewhat close to those of the sources. Such ratios can then be taken as good tracers of mantle heterogeneities (Joron and Treuil, 1977).

In Figure 3, Ta vs. Th contents have been plotted for a variety of North Atlantic basalts. The different lines on this diagram correspond to different ratios of these element contents at different sites. It can be noticed that the $\mathrm{Th} / \mathrm{Ta}$ ratio of 648B basalts differ clearly from the $\mathrm{Th} / \mathrm{Ta}$ composition of basalts of the MAR from higher latitudes which display different characteristics (enriched type basalts from the Reykjanes Ridge and from the Azores latitude ridge segment and transitional basalts from the south of the Azores to Kane fracture zone) (Bougault et al., 1979, 1985; Bougault and Treuil, 1980). The Th/Ta composition of these basalts from Hole 648B appears closely similar to that of basalts from similar latitudes in the Atlantic but located on older oceanic crusts (basalts of 10 m.y. in Holes 395-396 (Legs 45-46), and of 110 m.y. in Hole 417A (Legs 51-53) (Bougault et al., 1979; Joron et al., 1980). These basalts were erupted from this same ridge segment but at earlier times, thus were associated with the same flow line. In detail Hole 648B basalts and Holes 395-396 basalts display very close similarities of compositions (similar $\mathrm{Th} / \mathrm{Ta}(0.64$ to 0.81$), \mathrm{Th} / \mathrm{La}(0.030$ to 0.050$)$ ranges of composition), but some significant differences can be noticed with Hole $417 \mathrm{~A}$ basalts compositions, these last basalts showing more depleted characteristics ( $\mathrm{Th} / \mathrm{Ta}$ slightly lower $(0.40$ to 0.66$)$, lower $\mathrm{Th} / \mathrm{La}$ and $\mathrm{Th} / \mathrm{U}$ ratios $(0.017$ to 0.32 and 0.16 
Table 2 (continued).

\begin{tabular}{|c|c|c|c|c|c|c|c|c|c|c|c|c|c|c|c|c|c|}
\hline $\begin{array}{c}\mathrm{Ba} \\
\mathrm{NAA}\end{array}$ & $\begin{array}{c}\mathrm{Cs} \\
\mathrm{NAA}\end{array}$ & $\begin{array}{c}\mathrm{La} \\
\mathrm{NAA}\end{array}$ & $\begin{array}{l}\mathrm{Ce} \\
\mathrm{ID}\end{array}$ & $\begin{array}{l}\text { Nd } \\
\text { ID }\end{array}$ & $\begin{array}{l}\mathrm{Sm} \\
\text { ID }\end{array}$ & $\begin{array}{c}\text { Sm } \\
\text { NAA }\end{array}$ & $\begin{array}{l}\text { Eu } \\
\text { ID }\end{array}$ & $\begin{array}{c}\text { Eu } \\
\text { NAA }\end{array}$ & $\begin{array}{l}\text { Gd } \\
\text { ID }\end{array}$ & $\begin{array}{l}\text { Dy } \\
\text { ID }\end{array}$ & $\begin{array}{c}\text { Tb } \\
\text { NAA }\end{array}$ & $\begin{array}{l}\mathrm{Yb} \\
\mathrm{ID}\end{array}$ & $\begin{array}{c}\mathrm{Lu} \\
\text { NAA }\end{array}$ & $\begin{array}{c}\text { U } \\
\text { ID }\end{array}$ & $\begin{array}{c}\text { Th } \\
\text { NAA }\end{array}$ & $\begin{array}{c}\text { Ta } \\
\text { NAA }\end{array}$ & NAA \\
\hline 2.5 & - & 4.1 & - & - & - & 3.8 & - & 1.54 & - & - & 0.92 & - & 3.2 & - & 0.10 & 0.17 & 0.22 \\
\hline 7.6 & 0.07 & 4.8 & - & - & - & 4.5 & - & 1.86 & - & - & 1.09 & - & 3.8 & - & 0.10 & 0.16 & 0.23 \\
\hline- & - & 4.1 & - & 12.60 & 4.17 & - & 1.69 & - & 6.14 & 8.40 & - & 4.88 & - & 0.90 & 0.06 & 0.15 & 0.22 \\
\hline- & - & - & 12.3 & 11.84 & 3.91 & - & 1.46 & - & 5.22 & 5.91 & - & 3.75 & - & 0.68 & - & - & - \\
\hline 7.8 & 0.04 & 3.9 & - & 11.25 & 3.99 & - & 1.38 & - & 5.63 & 6.50 & - & 3.99 & - & 0.71 & 0.05 & 0.14 & 0.22 \\
\hline 4.6 & 0.03 & 4.0 & - & - & - & 3.7 & - & 1.50 & - & - & 0.90 & - & 3.1 & - & 0.07 & 0.14 & 0.21 \\
\hline 8.5 & 0.01 & 3.8 & - & - & - & 3.7 & - & 1.54 & - & - & 0.90 & - & 3.1 & - & 0.07 & 0.16 & 0.21 \\
\hline 5.0 & 0.02 & 4.0 & - & 11.53 & 3.77 & - & 1.39 & - & 5.55 & 6.43 & - & 4.23 & - & 0.77 & 0.07 & 0.17 & 0.21 \\
\hline 8.5 & 0.04 & 3.9 & - & 9.68 & 3.90 & - & 1.43 & - & 5.40 & 6.45 & - & 4.19 & - & - & 0.05 & 0.15 & 0.22 \\
\hline- & - & - & - & - & - & - & - & - & - & - & - & - & - & - & - & - & - \\
\hline
\end{tabular}
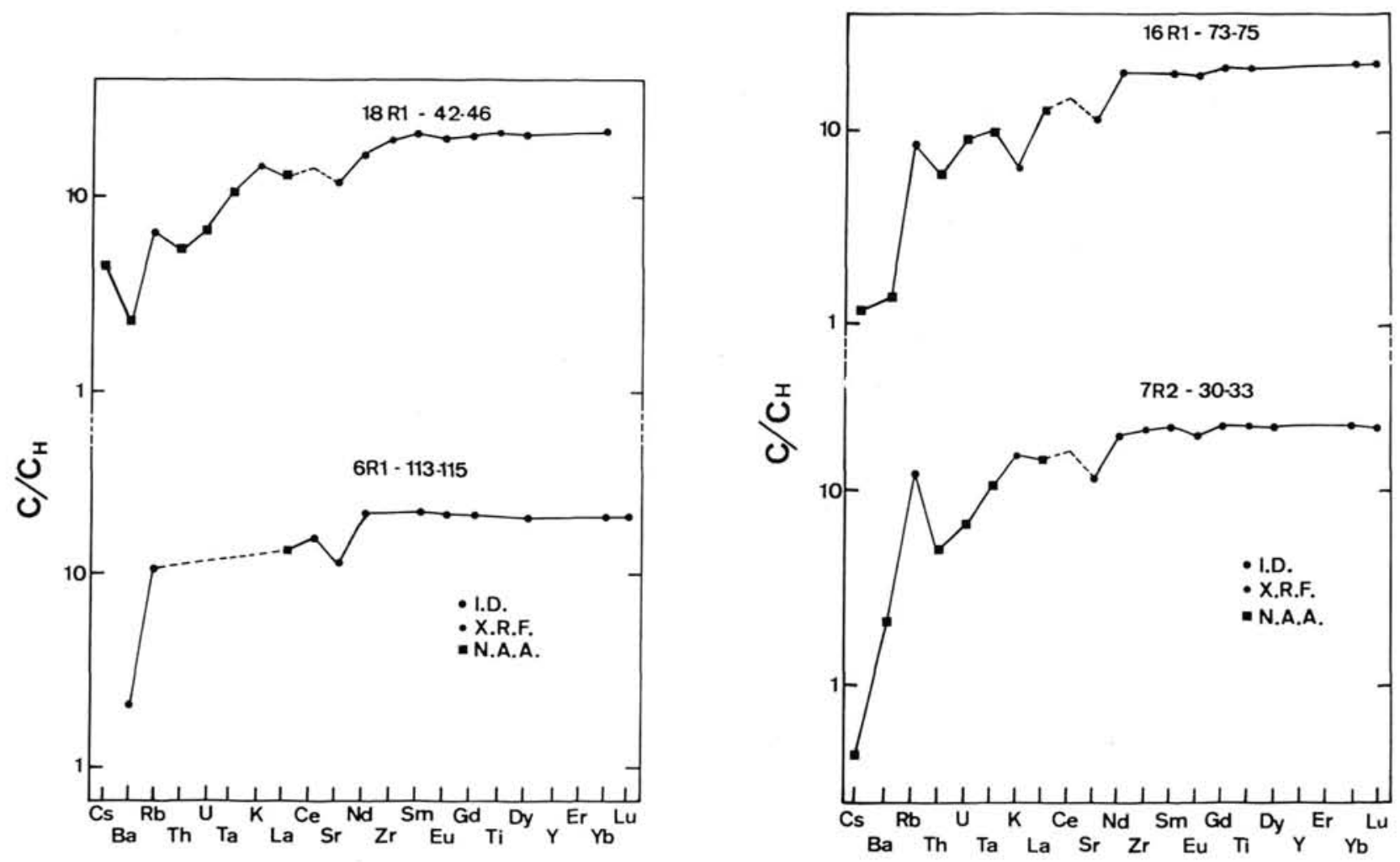

Figure 2. Incompatible-type trace element content of Hole 648B (Legs 106-109) N-MORB plotted in an extended REE chondrite normalized representation. Notice the slight Eu and stronger $\mathrm{Sr}$ negative anomalies attributed to a previous differentiation of plagioclase-bearing cumulates from the magmas. $\mathrm{Rb}$ displays relative large variations of contents assigned to low-temperature alteration effects (with precipitation of $\mathrm{K}, \mathrm{Rb}$ rich celadonite). 


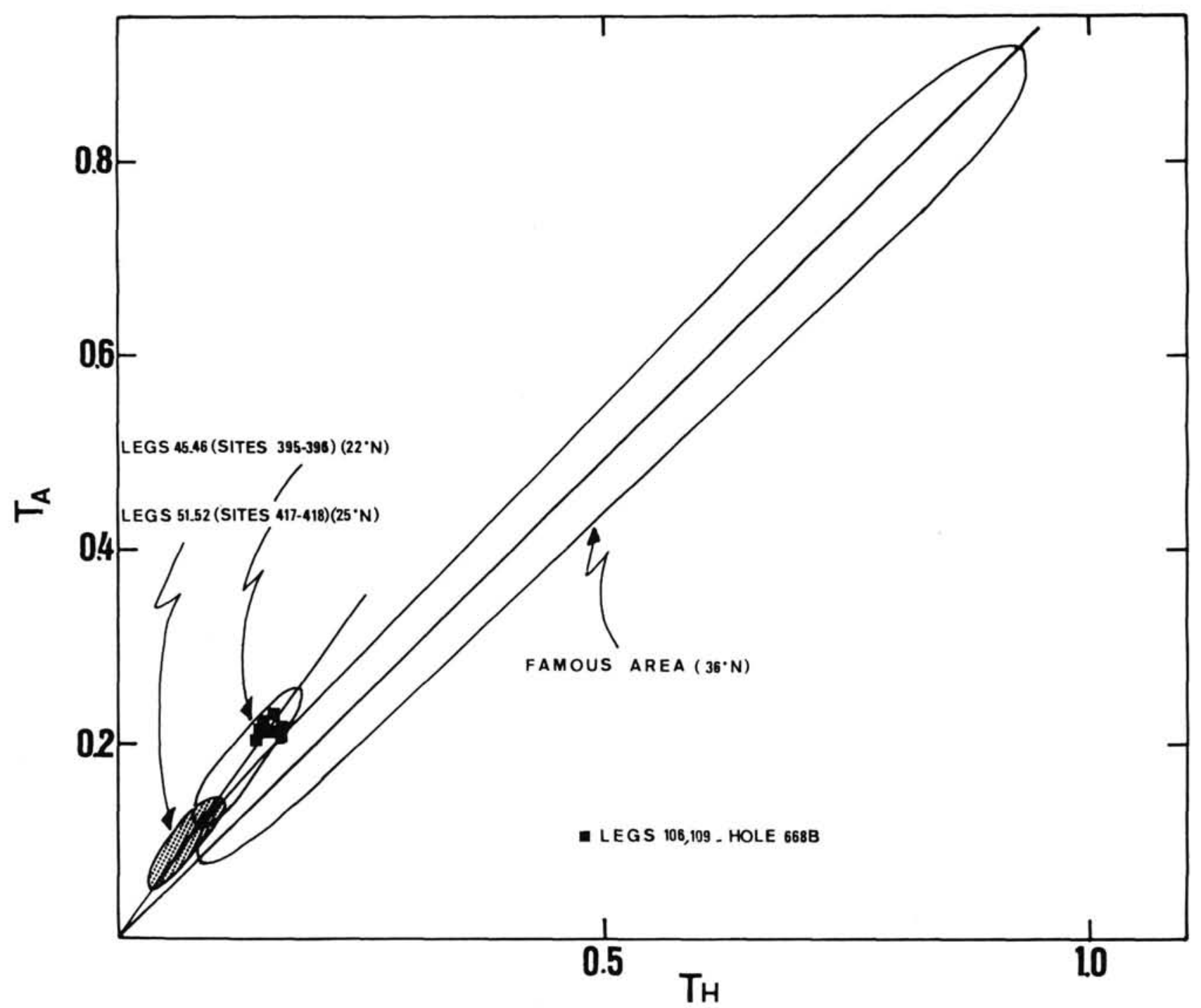

Figure 3. (Ta, Th) compositions of MAR basalts. Hole 648B basalts plot in the fields of other typical N-MORB (22 ${ }^{\circ} \mathrm{N}$ (Legs 45 and 46 ), $25^{\circ} \mathrm{N}$ (Legs 51 and 52)) which are characterized by low Th/Ta ratios. They differ clearly from Famous basalts compositions from higher latitudes $\left(36^{\circ} \mathrm{N}\right)$ which display higher Th/Ta ratios. Data from Bougault et al. (1978, 1979, 1985), Bougault and Treuil (1980), and Joron et al. (1979).

to 1.20 respectively). These data support the persistence in this ridge segment of a mantle source with depleted characteristics over the last 110 m.y., but with some variations over this period in the degree of depletion of the source.

Alkali element and Ba contents of Hole 648 B basalts-Low Temperature alteration imprint in these basalt compositions

Alkali element and $\mathrm{Ba}$ distributions are most often disturbed in basalts from old oceanic crusts by the effect of alteration processes (Humphris and Thompson, 1978; Staudigel and Hart, 1983; Alt et al., 1986). Consequently, the distribution of these elements in primitive oceanic basalts is very difficult to assess. These $648 \mathrm{~B}$ basalts offer an opportunity to obtain such an estimate.

Typical levels for Hole 648B basalts are 0.01-0.04 ppm Cs, $0.1 \%-0.3 \% \mathrm{~K}_{2} 0,1-3 \mathrm{ppm} \mathrm{Rb}$, and $2.5-8.5 \mathrm{ppm} \mathrm{Ba}$. Such low levels conform with the highly incompatible geochemical character of these elements in magmatic processes and the consequent noteworthy depletion we would expect in $\mathrm{N}$ MORB. Low incompatible element levels have also been found in other N-MORB from different places (west Costa Rica, Holes 499-500, Maury et al. 1985; East Pacific Rise, Joron et al., 1980) and also characterize the fresh basaltic rocks at the bottom of Holes 395-396 (Legs 45-46) and 417A (Legs 51-53) located in the same ridge flow line in older oceanic crust sections (respective ages $10 \mathrm{~m} . \mathrm{y}$. and $110 \mathrm{~m} . \mathrm{y}$.) (Bougault et al., 1979; Joron et al., 1979). In these holes the alkali element content increases from bottom to top. In Holes 395-396 (10 m.y. age), Rb increases from 1 to $10 \mathrm{ppm}, \mathrm{Cs}$ from 0.1 to $0.4 \mathrm{ppm}$. In Hole $417 \mathrm{~A}$ (110 m.y. age) the Rb content increases from 1 to $80 \mathrm{ppm}$ and Cs content from 0.1 to 0.8 $\mathrm{ppm}$. Precise alkali and Ba contents of the original fresh rocks at the bottom of these holes are difficult to assess as all of these rocks suffered a complex alteration history (with leaching, dissolution, and secondary phase precipitation), but it is interesting to note that these deeper rocks also display low alkali contents typical of $648 \mathrm{~B}$ basalt compositions.

The low temperature alteration process explains the enrichment of these elements in the upper part of these holes. This phenomenon is now well understood. As shown by 


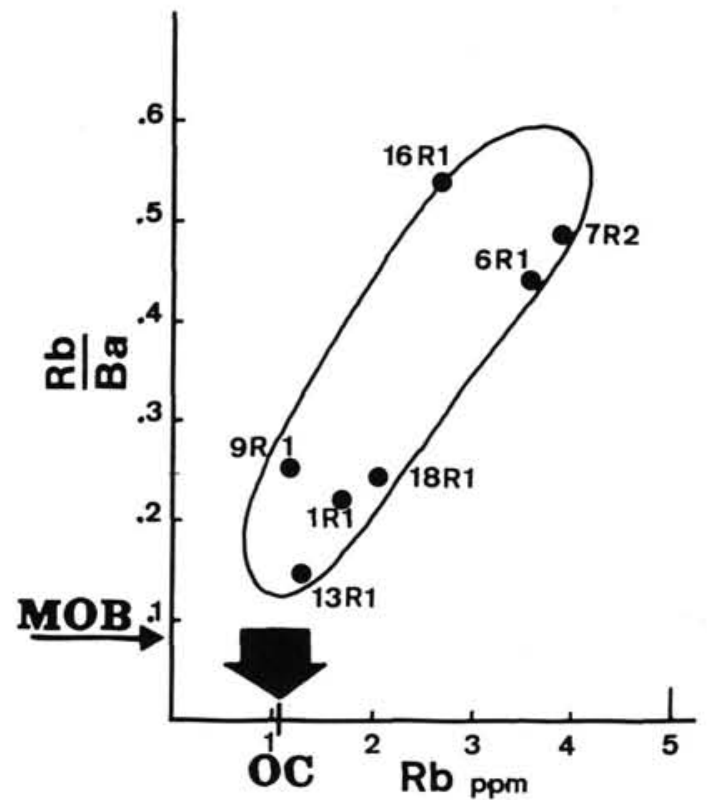

Figure $4 . \mathrm{Rb} / \mathrm{Ba}$ vs. $\mathrm{Rb}$ content of Hole $648 \mathrm{~B}$ basalts. $\mathrm{MOB}=$ Mean oceanic basalts. $\mathrm{Rb} / \mathrm{Ba}$ composition from Hofmann and White (1983) and resulting deduced original composition $(\mathrm{OC})$ of the $648 \mathrm{~B}$ basalts.

experimental studies, uptake of alkali elements from solutions to secondary phases derived from alteration processes, increases as temperature decreases (Berger et al., 1988). Thus, in altered basaltic sections, most of these elements introduced by seawater or by basalt dissolution will be held in the upper parts of the sections. Downhole this effect diminishes as the temperature increases. This effect is clearly observed in various oceanic crust sections (Staudigel and Hart, 1983; Alt, 1986; Alt et al., 1986). The continuous increase of alkali element content with increasing age in the upper part of the basaltic sections from Holes 395-396 to Hole 417A tends to indicate the long term permanency of this low temperature alteration. Low temperature alteration lasting for periods of around 10-15 m.y. has been demonstrated by Staudigel and Hart (1985) and Staudigel et al. (1986) in the Troodos ophiolitic body and Hole 504B, respectively. The observations made with respect to Holes 395-396 and 417 (continuous increase of alkali content from bottom to top and from Holes 395-396 to Hole 417) taken at face value tend to indicate that such a process lasted in these holes over a much longer period of time. This indicates that these basalts must have remained in contact with seawater throughout this period, probably for several reasons: lower thickness and/or higher permeability of the sediments overlying the oceanic crust section and permanency of sufficient permeability of the basalts.

Although rather fresh, Hole 648B rocks are not exempt from alteration features. As described in the ODP Legs 106/109 report (Detrick, Honnorez, Bryan, Juteau, et al., 1988) and in companion papers of this volume, incipient alteration has been noticed proceeding by the even penetration of water from fractures in the rocks. Original features displayed by the mobile elements in some rocks (i.e., the alkali, some calc-alkali, and $U$ elements) of this basaltic section might result from such incipient alteration process. We first summarize these features before discussing them:

1. The mobile elements show large range of compositions, with variations of a factor of 7 for Cs $(0.01-0.07 \mathrm{ppm})$, a factor of 4 for $\mathrm{Rb}(1-4 \mathrm{ppm})$, and a factor of 2 for $\mathrm{Ba}(4.5-8.5 \mathrm{ppm})$ and $U(0.05-0.10 \mathrm{ppm})$. Although we deal with very low

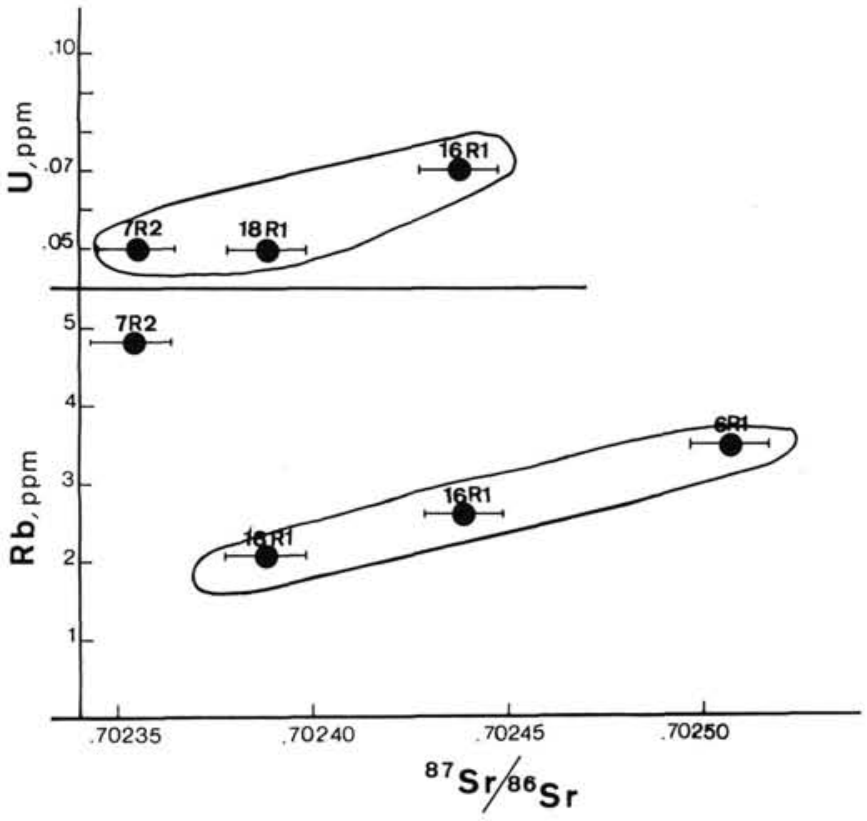

Figure 5. Hole $648 \mathrm{~B}$ basalts. ${ }^{87} \mathrm{Sr}{ }^{86} \mathrm{Sr}$ isotopic composition vs. U content (above) and vs. Rb content (below).

content levels, these variations are clearly greater than the analytical errors, and differ significantly from the range of variations of the immobile type elements $(20 \%-25 \%)$ in the section.

2. The $\mathrm{K} / \mathrm{U}$ ratio (from 11,000 to 36,500 ) and $\mathrm{Rb} / \mathrm{Ba}$ ratio (from 0.15 to 0.55 ) (Fig. 4) of the 648B basaltic rocks are greater than the mean values of these ratios in the oceanic basalts as given by Hofmann and White (1983) (respectively 12,500 and 0.08 ). These ratios are particularly high in some samples (16R-1, 6R-1, and 7R-2) (Fig. 4).

3. Although $\mathrm{Cs}$ and $\mathrm{Ba}$ elements display large variations of compositions they look only roughly correlated with $\mathrm{Rb}$; $\mathrm{U}$ and $\mathrm{Rb}$ do not show any particular correlation.

4. Although a few $\mathrm{Sr}$ isotopic measurements were made, slight differences in these isotopic compositions were noticed. Correlation of these differences in isotopic compositions with some alteration index yields different results. Figure 5 shows that some correlation between the $\mathrm{Sr}$ isotopic composition and the $\mathrm{U}$ content may exist, but the small number of rocks analyzed prevents us from giving any clear conclusion on the subject. Correlations with Rb seem to occur for three of the samples analyzed (Fig. 5) but Sample 7R-2 plots clearly outside the trend of these samples, as it displays a large $\mathrm{Rb}$ content associated with a low $\mathrm{Sr}$ isotopic composition.

The action of low temperature alteration and in particular the precipitation of celadonite during this process can explain some of these features, as the specific composition of samples such as 16R-1. Compared to most of the other rocks, this sample displays high $\mathrm{K} / \mathrm{U}$ and $\mathrm{Rb} / \mathrm{Ba}$ ratios, high $\mathrm{Rb}$ content, high ${ }^{87} \mathrm{Sr} /{ }^{86} \mathrm{Sr}$ composition. Major element analysis shows it is one of the few samples which is characterized by a significant $\mathrm{H}_{2} \mathrm{O}$ amount. All of these characteristics can have been induced by a low temperature alteration. Unfortunately no major element analysis (and $\mathrm{H}_{2} \mathrm{O}$ content) was done on the $6 \mathrm{R}-1$ sample which displays close compositions with $16 \mathrm{R}-1$ sample.

Sample 7R-2, although displaying a low $\mathrm{Sr}$ isotopic composition, is one of the few samples showing a high $\mathrm{Rb}$ content and $\mathrm{Rb} / \mathrm{Ba}$ ratio. This decoupling between the $\mathrm{Sr}$ isotopic 
composition and Rb content may be indicative of the occurrence of different kinds of processes managing the behavior of the elements during the alteration process. The Rb enrichment should result from celadonite precipitation, but the $\mathrm{Sr}$ isotopic increase (and $U$ enrichment as well) could result from some exchange between the solid basalt and fluid solutions. These two processes can be locally decoupled. This diversity of processes acting during the alteration process (dissolution, exchange, precipitation of phases) may explain the unclear correlation or absence of correlation between the various mobile elements (alkali, calc-alkali, and $U$ elements).

But another explanation can also be advanced in order to explain this diversity of compositions. This diversity may result from different primary compositions of the batches of magma, in particular in alkali elements contents. These elements, being more volatile than the other elements, can have different behaviors in magmatic processes. Such an effect is, however, very difficult to demonstrate or to refute, especially in the present case as we deal with very low ranges of compositions.

In conclusion, the effects of a low $\mathrm{T}$ alteration process can legitimately be supported in the case of a few samples which display specific compositions, explaining some alkali enrichments and some slight variations of the $\mathrm{Sr}$ isotopic compositions. This effect looks more problematic and may have been insignificant in most other samples, the noticed alkali element variations of compositions resulting possibly from primitive features of the magmas. Clearly more detailed studies are necessary in order to make precise these interpretations.

\section{CONCLUSIONS}

Hole 648B basalts display typical N-MORB geochemical characteristics, which resemble those of basalts from the same Atlantic flow line erupted $10 \mathrm{~m} . \mathrm{y}$. and $110 \mathrm{~m} . \mathrm{y}$. earlier. This shows the constancy of the mantle segment characteristics in this zone throughout this period of time. The lavas appear to have suffered a fractional crystallization differentiation process involving plagioclase-bearing cumulates before their emission.

The alkali element and $\mathrm{Ba}$ contents of these lavas is typically very low, indicating high depletion of these elements in the mantle source. The imprint of an incipient low temperature alteration can be noticed in the alkali elements (alkali elements, K, Rb enrichment), U, and ${ }^{87} \mathrm{Sr} /{ }^{86} \mathrm{Sr}$ isotopic compositions of a few samples.

\section{ACKNOWLEDGMENTS}

This work benefited from long discussions with all the Leg 109 scientific party of the JOIDES Resolution and thereafter. It was financially supported by INSU (ODP-France Program).

\section{REFERENCES}

Allegre, C. J., 1982. Chemical geodynamics. Tectonophysics, 81:109. Allegre, C. J., and Minster, J. F., 1978. Quantitative models of trace element behavior in magmatic processes. Earth. Planet. Sci. Lett., 38:1.

Allegre, C. J., and Turcotte, D. L., 1986. Implications of a twocomponent marble-cake mantle. Nature, 323:123-127.

Alt, J. C., 1986. Alteration of the upper oceanic crust: Mineralogy and processes in Deep Sea Drilling Project Hole 504B, Leg 83. In Anderson, R. N., Honnorez, J., Becker, K., et al., Init. Repts. DSDP, 83: Washington (U.S. Govt. Printing Office), 395-419.

Alt, J. C., Honnorez, J., Laverne, C., and Emmermann, R., 1986. Hydrothermal alteration of a $1 \mathrm{~km}$ section through the upper oceanic crust, Deep Sea Drilling Project Hole 504B: Mineralogy, chemistry and evolution of seawater-basalt reactions. J. Geophys. Res., 91:10309-10335.
Berger, G., Schott, J., and Guy, C., 1988. Behavior of Li, Rb and Cs during basalt glass and olivine dissolution and chlorites, smectites and zeolites precipitation from seawater. Experimental investigations and modelisations between $50^{\circ}$ and $300^{\circ} \mathrm{C}$. Chem. Geol., $71: 297-314$

Bougault, H., 1980. Contribution des éléments de transition a la compréhension de la génèse des basaltes océaniques. [State thesis]. Univ. Paris VII.

Bougault, H., Cambon, P., and Toulhouat, H., 1977. X Ray spectrometric analysis of trace elements in rocks. Correction for Instrumental interferences. X-Ray Spectrometry, 6:66-72.

Bougault, H., Cambon, P., Joron, J. L., and Treuil, M., 1978. Trace elements: fractional crystallization and partial melting processes, heterogeneity of the upper mantle material. In Dmitriev, L., Heirtzler, J., et al., Init. Repts. DSDP, 46: Washington (U.S. Govt. Printing Office), 247-251.

Bougault, H., Joron, J. L., and Treuil, M., 1979. Alteration, fractional crystallization, partial melting, mantle properties from trace elements in basalts recovered in the North Atlantic. In Talwani, M., Harrison, C. G., and Hayes, D. E. (Eds.), Deep Drilling Results in the Atlantic Ocean: ocean crust Washington (Am. Geophys. Union), Maurice Ewing Series, 2:352-368.

Bougault, H., and Treuil, M., 1980. Mid-Atlantic Ridge - zero age geochemical variations between Azores and $22^{\circ} \mathrm{N}$. Nature, 286: 209-212.

Bougault, H., Joron, J. L., Treuil, M., and Maury, R., 1985. Local versus regional mantle heterogeneities evidence from hygromag maphile elements. In Bougault, H., Cande, S. C., et al., Init. Repts. DSDP, 82: Washington (U.S. Govt. Printing Office), 459-482.

Bryan, W. B., Thompson, G., Frey, F. A., and Dickey, J. J., 1976. Inferred settings and differentiation in basalts from the Deep Sea Drilling Project. J. Geophys. Res., 81:4285-4304.

Bryan, W. B., and Sargent, D., 1978. Basalt from $22-23^{\circ} \mathrm{N}$, Mid Atlantic Ridge median valley. In Melson, W. G., Rabinowitz, P. D., et al.: Washington (U.S. Govt. Printing Office), 653-655.

Bryan, W. B., Thompson, G., and Ludden, J. N., 1981. Compositional variation in Normal MORB from $22^{\circ}-25^{\circ} \mathrm{N}$, Mid-Atlantic Ridge and Kane Fracture Zone. J. Geophys. Res., 86:11815-11836.

Detrick, R. B, Honnorez, J., Bryan, W. B, Juteau, T., et al., 1988. Proc. ODP, Init. Repts, 106/109: College Station, TX (Ocean Drilling Program).

Donnelly, T., Francheteau, J., Bryan, W., Robinson, P. T., Flower, M.F.J., Salisbury, M., et al., 1980. Init. Repts. DSDP, 53, Pt. 2: Washington (U.S. Govt. Printing Office).

Drake, N.E.R., Rhodes, J. M., and Autio, L. K., 1985. Geochemistry of basalts from Deep Sea Drilling Project Hole 556-564. In Bougault, H., Cande, S. C., et al., Init. Repts. DSDP, 82: Washington (U.S. Govt. Printing Office), 421-438.

Dupre, B., and Allegre, C. J., 1983. Pb-Sr isotope variation in Indian Ocean basalts and mixing phenomena. Nature, 303:142-146.

Frey, F. A., Bryan, W. B., and Thompson, G., 1974. Atlantic Ocean floor geochemistry and petrology basalts from Legs 2 and 3 of the Deep Sea Drilling Project. J. Geophys. Res., 79:5507-5527.

Hart, S. R., 1984. A large scale isotope anomaly in the Southern Hemisphere mantle. Nature, 309:753-757.

Hertogen, J., Sachtleben, T. H., Schmincke, H. U., and Jenner, G. A., 1985. Trace element geochemistry and petrogenesis of basalts from Deep Sea Drilling Project Sites 556-559 and 561-564. In Bougault, H., Cande, S. C., et al., Init. Repts. DSDP, 82: Washington (U.S. Govt. Printing Office), 449-457.

Hofmann, A. W., and White, W. M., 1982. Mantle plumes from ancient oceanic crust. Earth. Planet. Sci. Lett., 57:421-436.

1983. $\mathrm{Ba}, \mathrm{Rb}$ and $\mathrm{Cs}$ in the Earth mantle. Z. Naturforsch. $38: 256-266$

Honnorez, P., 1981. The aging of the oceanic crust at low temperature. In Emiliani (editor), The Sea, New York (Wiley), 7:525-587.

Humphris, S. E., and Thompson, G., 1978. Trace element mobility during hydrothermal alteration of oceanic basalts. Geochim. Cosmochim. Acta, 42:127-136.

Jaffrezic, H., Joron, J. L., and Treuil, M., 1977. Trace element determination in rock powder. A study of the precision for a given analytical procedure instrumental epithermal neutron activation. J. Radio. Anal. Chem., 39:185-188. 
Joron, J. L., Bollinger, C., Quisefit, J. P., Bougault, H., and Treuil, M., 1979. Trace elements in Cretaceous basalts at $25^{\circ} \mathrm{N}$ in the Atlantic Ocean: alteration, mantle compositions, and magmatic processes. In Donnelly, T., Francheteau J., Bryan, W., Robinson, P., Flower M., Salisbury, M., et al., Init. Repts. DSDP, 51, 52, 53, Pt.2: Washington (U.S. Govt. Printing Office), 1087-1098

Joron, J. L., Briqueu, L., Bougault, H., and Treuil, M., 1980. East Pacific Rise, Galapagos Spreading Center and Siqueiros Fracture Zone, Deep sea Drilling Project Leg 54 Hygromagmatophile elements-A comparison with the North Atlantic. In Rosendahl, B., Hekinian, R., et al., Init. Repts. DSDP, 54: Washington (U.S. Govt. Printing Office), 725-735.

Joron, J. L., and Treuil, M., 1977. Utilisation des propriétés des éléments fortement hygromagmatophiles pour l'étude de la composition chimique et de l'hétérogénéité du manteau. Bull. Soc. Geol. Fr., 7:1197-1205.

Langmuir, C. H., Bender, J. F., Bence, A. E, Hanson, G. N., and Taylor, S. R., 1977. Petrogenesis of basalts from the FAMOUS area Mid-Atlantic Ridge. Earth. Planet. Sci. Lett., 36:133-156.

Le Douaran, S., and Francheteau, J., 1981. Axial depth anomalies from 10 to $50 \mathrm{~W}$ north along the Mid-Atlantic Ridge correlation with other mantle properties. Earth. Planet. Sci. Lett., 54: 29-47.

Loubet, M., Sassi, R., and Di Donato, G., 1988. Mantle heterogeneities combined isotope and trace element approach and evidence for recycled continental crust materials in some OIB sources. Earth. Planet. Sci. Lett., 89:299-315.

Maury, R. C, Bougault, H., Joron, J. L., Girard, D., Treuil, M., Azema, J., and Auboin, J., 1985. Volcanic rocks from Leg 67 sites: mineralogy and geochemistry. In Auboin, J., Von Huene, R., et al., Init. Repts. DSDP., 67: Washington (U.S. Govt Printing Office), 557-576.

Melson, W. G, Thompson, G., and Andel, T. van., 1968. Volcanism and metamorphism in the Mid-Atlantic Ridge, $22^{\circ} \mathrm{N}$ latitude, $J$. Geophys. Res., 73:5925-5941.

Mottl, M. J., 1983. Metabasalts, axial hot springs and the structure of hydrothermal systems at mid-ocean ridges. Bull. Geol. Soc. Am., 94:161-180.

Richard, P., Shimizu, N., and Allegre, C. J., $1976 .{ }^{143} \mathrm{Nd} /{ }^{144} \mathrm{Nd}$ a natural tracer an application to oceanic basalts. Earth. Planet. Sci. Lett., 31:169-178.

Ringwood, A. E., 1982. Phase transformations and differentiation in subducted lithosphere implications for mantle dynamics, basalt petrogenesis and crustal evolution. J. Geol., 90:611-643.

Schilling, J. G., 1973. Iceland mantle plumes Geochemical evidence along Reykjanes Ridge. Nature, 242:565-571.

1975. Azores mantle blob: rare earth evidence, Earth.

Planet. Sci. Lett., 25:102-115.
Schilling, J. G., Zajac, M., Evans, R., Johnston, T., White, W., Devine, J. D., and Kingsley, R., 1983. Petrologic and geochemical variations along the Mid-Atlantic Ridge from $29^{\circ} \mathrm{N}$ to $73^{\circ} \mathrm{N}$. Am. J. Sci., 283:510-586.

Shipboard Scientific Party, 1988. Site 648. In Detrick, R. B., Honnorez, J., Bryan, W. B., Juteau, T., et al., Proc. ODP, Init. Repts. 106-109: College Station, TX (Ocean Drilling Program), 35-134.

Staudigel, H., 1979. Chemical analyses of interlaboratory standards In Donnelly, T., Francheteau, J., et al., Init. Repts. DSDP, 51, 52, 53, Pt. 2: Washington (U.S. Govt. Printing Office), 1331-1333].

Staudigel, H., and Hart, S. R., 1983. Alteration of basaltic glass: processes and significance for the oceanic crust-seawater budget. Geochim. Cosmochim. Acta, 47;337-350.

1985. Dating of ocean hydrothermal alteration strontium isotope ratios from Hole 504B carbonates and a reinterpretation of $\mathrm{Sr}$ isotope data from Deep Sea Drilling Project Sites 105, 332, 417, and 418. In Anderson, R. N., Honnorez, J., Becker, K., et al., Init Repts. DSDP, 83: Washington (U.S. Govt. Printing Office), 297-303.

Staudigel, H., Gillis, K., and Dreucau, R., 1986. K/Ar and Rb/Sr ages of celadonites from the Troodos ophiolite, Cyprus. Geology, 14:72-75.

Treuil, M., and Joron, J. L., 1975. Utilisation des elements hygromagmatophiles pour la simplification de la modélisation quantitative des processus magmatiques, exemples de l'Afar et de la dorsale medio Atlantique. Soc. It. Mineral. Petrol, 31:125-174.

Tual, E., Jahn, B. M., Bougault, H., and Joron, J. L., 1985. Geochemistry of basalts from Hole 504B, Leg 83, Costa Rica Rift. In Anderson, R. N., Honnorez J., Becker, K., et al., Init. Repts. DSDP, 83: Washington (U.S. Govt. Printing Office), 201-214.

Weaver, B. L., Tarney J., and Saunders, A. D., 1987. Geochemistry and mineralogy of basalts recovered from the central North Atlantic. In Bougault, H., Cande, S. C., et al., Init. Repts. DSDP, 82: Washington (U.S. Govt. Printing Office), 395-419.

White, W. M., and Schilling, J. G., 1978. The nature and origin of geochemical variation in Mid-Atlantic Ridge basalts from the Central North Atlantic. Geochim. Cosmochim. Acta, 42:1501-1516.

Wood, D. A., Joron, J. L., Treuil, M., Norry, N., and Tarney, J., 1979. Elemental and $\mathrm{Sr}$ isotope variations in basic lavas from Iceland and the surrounding ocean floor. Contrib. Mineral. Petrol., 70:319-339.

Zindler, A., and Hart, S., 1986. Chemical geodynamics. Ann. Rev. Earth. Planet. Sci., 14;493-571.

Date of initial receipt: 29 June 1988

Date of acceptance: 1 May 1989

Ms 106/109B-123 